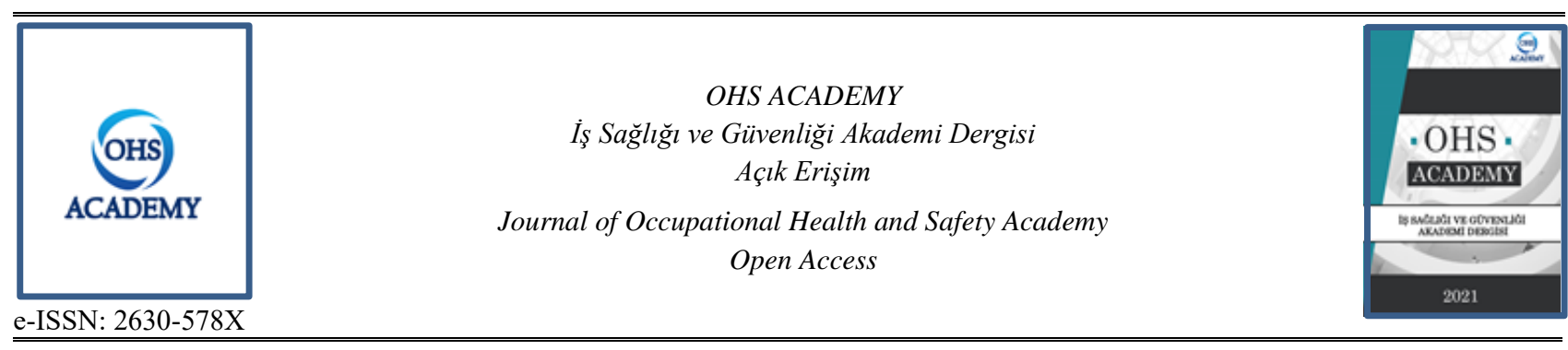

\begin{tabular}{llr}
\hline \hline 10.38213/ohsacademy.822861 & Y11, Cilt 4, Say1 1, Sayfa: 27-43 & https://dergipark.org.tr/tr/pub/ohsacademy
\end{tabular}

\title{
İş Sağlığı ve Güvenliğinde Metal İşleme Sıvıları
}

\author{
Okan DUMAN $^{1 *}$, Yahya BOZKURT ${ }^{2}$ \\ ${ }^{1}$ Aile, Çalışma ve Sosyal Hizmetler Bakanlığı, Rehberlik ve Teftiş Başkanlığı, İstanbul, Türkiye \\ ${ }^{2}$ Marmara Üniversitesi, Teknoloji Fakültesi, Metalürji ve Malzeme Mühendisliği Bölümü, İstanbul, Türkiye
}

\begin{abstract}
Makale Tarihçesi
Gönderim: $\quad 07.11 .2020$

Kabul: $\quad 15.04 .2021$

Yayım: $\quad 30.04 .2021$
\end{abstract}

Derleme Makalesi
Öz- Talaşlı imalat başta olmak üzere metallerin işlenmesi operasyonlarında metal işleme sıvıları ihtiyaç duyulan en temel malzemelerden biridir. Endüstride bilinen ismi bor yağı olmakla beraber kesme yağı, emülsiyon sıvısı, soğutma sıvısı, metal uzaklaştırma sıvısı, metal işleme sıvısı/yağı vb. tabirler ile tanımlanır. Söz konusu akışkanlar çalışan sağlığı yönünden cilt rahatsızlıkları, solunum rahatsızlıkları, kanser vb. riskler barındırmaktadır. Bu sıvılar, operasyon sürecinde sıcaklık etkisiyle buhar (sis, bulut, buğu) haline gelerek ciddi solunum problemlerine sebep olabileceği gibi ortam şartlarından etkilenmesiyle özellikleri kötüleșerek temas sonucu cilt hastalıklarına da yol açabilmektedir. $\mathrm{Bu}$ bağlamda birçok ülkede söz konusu akışkanlara maruziyeti azaltmak için araştırmalar ve tartışmalar yapılmaktadır. Metal işleme sıvılarından kaynaklı tehlikelerin öncelikle yeterli ve güncel bilgiler edinilerek tanımlanması önem teşkil etmektedir. Söz konusu sıvıların çalışan sağlığına etkileri, maruziyet türü, düzeyi, şiddeti ve kullanılan akışkanın tipine göre değișiklik göstermektedir. Bu çalıșmada metal ișleme sıvıları tanıtılarak kısa veya uzun vadede söz konusu akışkanların çalışan sağlığına etkileri ve alınması gerekli tedbirlere ilişkin iş sağlığı ve güvenliği açısından bir perspektif sunulması amaçlanmış olup, sonuç olarak metal işleme sıvılarının çalışan sağlığına etkileri ve bunlara karşın alınması gerekli teknik ve organizasyonel tedbirler, ulusal mevzuat ile uluslararası çalışmalar da dikkate alınarak ortaya konulmuştur.

Anahtar Kelimeler - Metal ișleme Siviları, Talaşlı İmalat, İş Sağlı̆̆ı ve Güvenliği, Mesleki Maruziyet

\section{Metalworking Fluids (MWF) in Occupational Health and Safety}

\author{
Okan DUMAN $^{2 *}$, Yahya BOZKURT ${ }^{2}$ \\ ${ }^{1}$ The Ministry of Family, Labour and Social Services, Guidance and Inspection Department, Istanbul, Turkey, \\ ${ }^{2}$ Marmara University, Faculty of Technology, Metallurgical and Materials Engineering Department, Istanbul, \\ Turkey
}

$\begin{array}{ll}\text { Article History } \\ \text { Received: } & 07.11 .2020 \\ \text { Accepted: } & 15.04 .2021 \\ \text { Published: } & 30.04 .2021\end{array}$

Review Article

\begin{abstract}
Metalworking fluids (MWF) are one of the basic materials in metalworking processes. It is defined as terms such as cutting oil, emulsion liquid, coolant, metal removal fluid, metal working fluid/oil; as well as boron oil is a well-known name. MWF have health risks such skin, respiratory diseases, cancer etc. These fluids may form vapor (mist) with temperature effect during process, and cause serious respiratory and skin diseases as a result of coming into contact with these MWF that is deteriorated by environmental conditions. In this context, many countries research and discuss to reduce exposure to MWF. It is important to identify the hazards from MWF by obtaining adequate and current information. The effects of MWF on occupational health vary on exposure type, level, severity and type of fluid. It is aimed to present a perspective in terms of occupational health and safety in the short or long term regarding the effects of MWF on employee health and the necessary precautions by introducing MWF in this study and as a result, the effects of MWF on employee health and the technical and organizational measures required are put forward by taking into account the national legislation and international studies.
\end{abstract}

Keywords - Metalworking Fluids, Machining, Occupational Health and Safety, Occupational Exposure

1okan.duman@ailevecalisma.gov.tr (1) 0000-0001-5504-6338

2 ybozkurt@marmara.edu.tr (1) 0000-0003-1816 5922

*Sorumlu Yazar / Corresponding Author: okdmn@gmail.com, İstanbul 


\section{Giriș}

Metal işleme proseslerinde kullanımı her geçen zaman artmakta olan metal işleme sıvılarının çalışan sağlığına olumsuz etkileri daha sık gündeme gelmeye başlamış ve söz konusu kimyasalların doğru yönetilememesi halinde çalışanlar için ciddi sağlık risklerine yol açtığ farklı çalışmalarla ortaya konulmuştur.

Metal işleme sıvılarının karmaşık kimyasal yapıları dikkate alındığında, çalışan sağlı̆̆ı üzerine etkilerinin değerlendirilmesinde öncelikle kullanılan akışkanın özelliklerinin iyi bilinmesi önem teşkil etmektedir. İş sağlı̆̆ ve güvenliği yönünden risk değerlendirmesi ve buna bağlı süreç kontrolü doğru yapılamadığı takdirde çalışanların doğrudan akışkana veya dolaylı olarak buharlarına maruziyeti en temel iş sağlığı ve güvenliği sorunları olarak ortaya çıkacaktır.

Endüstride kullanılan metal işleme sıvıları su ile karıştırılarak veya karıştırılmadan olmak üzere iki türlü kullanılmaktadır. CNC makinelerinde yoğun olarak kullanılan bu sıvılar pompalar ile borulardan çalışma parçasına iletilmekte ve operasyon sonunda tekrar depolandığı hazneye geri dönmektedir. Bu sirkülasyon sürecinde tezgâh elemanlarından gelen yağlar da hazneye karışarak genelde akışkanın üzerinde birikirken, bunun yanında oluşan metal talaş ve tozları gibi partiküllerin de haznede toplanmasıyla oluşan kirlilik akışkanın bakımını zorlaştırmaktadır (3-S Mühendislik, 2011).

Metal işleme sıvılarının zamanla özelliklerini kaybederek biyolojik bozulma eğiliminde olması ve bu duruma maruz kalan çalışanlar için barındırdığı sağlık riskleri, bu bağlamda alınacak teknik ve organizasyonel önlemleri kaçınılmaz kılmaktadır. Söz konusu bozulma sürecinin kontrol altına alınabilmesi için başta konsantrasyon, nötralizasyon $(\mathrm{pH})$ ve bakteri miktarı olmak üzere belirli parametrelerin düzenli olarak kontrolü yapılmalıdır. Su ile karışabilen yani emülsiyon halindeki metal işleme sıvılarının kontrolü kapsamında belirlenen parametreler, ölçüm periyotları, sınır değerler ve alınması gerekli tedbirler Tablo 1'de gösterilmiştir (Çevre ve Şehircilik Bakanlığ 1,2012 ).

Metal işleme sıvılarının biyolojik bozulması yanında kullanım sürecinde isınarak ya da ortam şartlarında buharlaşarak çalışma ortamı için ciddi bir kirletici olabileceği ihtimali yapılacak risk değerlendirmesi çalışmalarında titizlikle ele alınmalıdır. Çalışanların maruziyeti sonucu ortaya çıkacak etkilerin uzun vadede çıkma ihtimali de dikkate alınarak meslek hastalığına sebep olabilecek etkenlerin sorgulanması da önem teşkil etmektedir.

Tablo 1. Emülsiyon Kontrolüne İlişkin Hususlar (Consideration of Emulsion Control) (Çevre ve Şehircilik Bakanlığı, 2012).

\begin{tabular}{|c|c|c|c|c|}
\hline Parametre & $\begin{array}{c}\text { Genel Kullanım } \\
\text { Alanı (Uyarı Sinyali) }\end{array}$ & Ölçme Sistemi & $\begin{array}{l}\text { Haftalık } \\
\text { Ölçüm }\end{array}$ & Tedbirler \\
\hline Konsantrasyon & $\begin{array}{l}\text { \% 2-10 (kullanıma özgü), } \\
\text { (Yaklaşık \%5'lik sapma) }\end{array}$ & $\begin{array}{l}\text { Refraktometre, } \\
\text { Ayırma pistonları }\end{array}$ & $2-3$ & $\begin{array}{l}\text { Çok ince olması halinde yağlı emülsiyon } \\
\text { ilave edilir. Çok yağlı olması halinde ise } \\
\text { yağsı emülsiyon katarak inceltilir }\end{array}$ \\
\hline Asitlik Derecesi & $\begin{array}{l}\text { Yaklaşık } 9 \text { (ürüne özgü), } \\
\text { (Belirgin azalma) }\end{array}$ & $\begin{array}{l}\mathrm{pH}-\text { Kağıt } \\
\mathrm{pH}-\text { Metre }\end{array}$ & $1-2$ & $\begin{array}{l}\text { Aşağıdakiler için gösterge: } \\
\text { - Konsantrasyon değişikliği } \\
\text { - Çok fazla bakteri bulunma } \\
\text { - Eskime }\end{array}$ \\
\hline Bakteri Miktarı & $\begin{array}{l}>10^{4} \text { bakteri } / \mathrm{ml} \\
\left(>10^{6} \text { bakteri } / \mathrm{ml}\right)\end{array}$ & $\begin{array}{l}\text { Bakteri göstergeleri, } \\
\text { Dip-Slides }\end{array}$ & 1 & $\begin{array}{l}\text { Biyosit ilavesi, } \\
\text { Gerekirse kesme sıvısı değişimi }\end{array}$ \\
\hline Nitrit Oranı & $\begin{array}{l}0-10 \mathrm{mg} / 1 \\
(>20 \mathrm{mg} / \mathrm{l})\end{array}$ & $\begin{array}{l}\text { Nitrat ölçüm çubuğu, } \\
\text { Analiz }\end{array}$ & 1 & $\begin{array}{c}\text { Nitrosamin analizi } \\
\text { (Kesme sıvısı değişimi tesbiti için) }\end{array}$ \\
\hline İletkenlik & $\begin{array}{l}100-1000 \mu \mathrm{s} \\
(>5000 \mu \mathrm{s})\end{array}$ & İletkenlik ölçüm cihazı & 0,5 & $\begin{array}{l}\text { Çözülmüş ağır metaller gibi zararlıların } \\
\text { yüksek oranda bulunduğunun göstergesi, } \\
\text { Analiz ve gerekirse kesme sıvısı değişimi }\end{array}$ \\
\hline Is1 & $\begin{array}{l}\text { ca. } 20^{\circ} \mathrm{C} \\
\left(>25^{\circ} \mathrm{C}\right)\end{array}$ & Termometre & $\begin{array}{l}\text { Sinır 1S1 } \\
\text { değeri }\end{array}$ & $\begin{array}{c}\text { Banyo büyüklüğünün kontrol edilmesi, } \\
\text { Soğutma sistemi }\end{array}$ \\
\hline Biyosit & $\begin{array}{l}\text { - maddeye özgü } \\
\text { (örn. Formaldehid-ayracı } \\
\% 0,1-0,2)\end{array}$ & Analiz & $1-2$ & Hedefli ilave dozaj \\
\hline
\end{tabular}




\section{Materyal ve Yöntem}

Çalışmada kullanılan veriler bilimsel tarama yöntemi kapsamında doküman inceleme ve veri toplama tekniği ile elde edilmiş olup araştırmacının saha bilgileri ile de desteklenmiştir. Bu çalışmada metal işleme sıvıları; söz konusu akışkanların tanıtılması, kısa ve uzun vadede çalışan sağlığına etkileri ile iş sağlığı ve güvenliği yönünden alınması gerekli tedbirler olmak üzere üç aşamada ele alınmıştır. Çalışmada ulusal mevzuat ile özelikle uluslararası çalışmalar kapsamında ABD'de yerleşik Occupational Safety and Health Administration (OSHA) ile The National Institute for Occupational Safety and Health (NIOSH) uygulamaları dikkate alınmıştır.

\section{Metal İșleme Sıvıları}

Talaşlı imalat işlemlerinde ortaya çıkan problemlerin çözümü için metal işleme sıvıları kullanılmaktadır. Talaşlı imalat kapsamında yapılan kesim işlemi sırasında oluşan 1sı ile ortaya çıkan yüksek sıcaklıkların $\left(350-1000{ }^{\circ} \mathrm{C}\right)$ düşürülmesi ve yağlama etkisiyle takım-talaş ara yüzeyindeki sürtünmenin azaltılması bu sıvıların kullanımı ile sağlanırken operasyon bölgesinden talaşın uzaklaştırılmasına da destek sağlanmış olunur. Böylece hem takım ömrünün uzamasında hem de ürünün kalitesinde artış sağlanmış olur (Şahin, 2001).

Metal işleme sıvılarının yağlama ve soğutma olmak üzere sahip oldukları iki temel işlev; suyun soğutma ve yağın yağlama özelliklerinin antikorozif, emülgatör vb. katıklar ile çeşitli kombinasyonlarıyla sağlanmaktadır (Erel ve Iş̧1k Coşkunses, 2012).

Yağlama işlevinin soğutma işlevine göre daha gerekli olduğu yerlerde, saf yağlar sulandırılmadan katkı maddeleri ile karışımı sağlanarak kullanımı tercih edilmektedir. Kesme yağı olarak da bilinen bu metal işleme sıvıları genellikle mineral yağlar olarak adlandırılmaktadır. Mineral yağlara domuz yağı, kunduz yağı, kükürt ve klorit gibi katkılar katılabilmekledir. Katkısız mineral yağların kullanım alanı genellikle işlenebilirliği yüksek alüminyum, magnezyum gibi metaller ile kükürtlü otomat çelikleri olmaktadır. Katıklı yağlar ise vida, diş, delik açma gibi ağır işlemlerde kullanılmaktadır. Katıklı yağlar fiyatlarının yüksekliği, ateşlenme tehlikesi ve insan sağlığına olumsuz etkisinden dolayı pek tercih edilmemektedir (Akkurt, 2004). Saf su ise geçmişte kullanılan ilk soğutma sıvısını olmasına rağmen yağlayıcılık özelliğinin iyi olmaması ve korozyon etkilerinden dolayı günümüzde kullanımı tercih edilmemektedir.

Metal işleme sıvılarının temel bileşenleri; mineral yağlar, bitkisel yağlar, sentetik yağlar ve bakteri-mantar önleyici kimyasallar dâhil çeşitli katkı maddeleridir. Metal işleme sıvılardan; çözünebilen/çözünür yağlar, yarı sentetik ve sentetik yağlar su ile emülsiyon yapılarak kullanılır. Bütün metal işleme sıvıları stabilizatörler, biyositler, seyrelticiler, boyalar, koku yayarlar gibi katkı maddeleri içerebilir (Frank ve Revonna, 2011). Metal işleme sıvıları Tablo 2'de gösterildiği gibi sınıflandırılabilmektedir:

Tablo 2. Metal İșleme Sıvılarının Sınıflandırılması

\begin{tabular}{|c|c|c|c|}
\hline Yağ Bazlı & \multicolumn{3}{|c|}{ Su Bazlı } \\
\hline Su ile karışmayan & \multicolumn{3}{|c|}{ Su ile karışabilen } \\
\hline Saf Yağlar (\%100 yağ) & $\begin{array}{l}\text { Çözünebilen Yağlar } \\
\text { (\%60-90 yağ) }\end{array}$ & $\begin{array}{c}\text { Yarı Sentetikler Sıvılar } \\
(\% 2-30 \text { yağ })\end{array}$ & $\begin{array}{l}\text { Sentetik Sivılar } \\
\text { (\%0 yağ) }\end{array}$ \\
\hline $\begin{array}{l}\text { Mineral Yağlar } \\
\text { Hayvansal Yağlar } \\
\text { Bitkisel Yağlar }\end{array}$ & Mineral Yağ+Emülgatör & $\begin{array}{c}\text { Çözünebilen } \\
\text { Yağlar+Sentetik Yağlar }\end{array}$ & Su+Organik Kimyasallar \\
\hline
\end{tabular}

Sanayide yüzlerce çeşit metal işleme sıvısı kullanılmakla beraber söz konusu sıvılar yukarıdaki tabloda belirtildiği gibi genel anlamda saf, çözünür, yarı sentetik ve sentetik olmak üzere 4 farklı kategoride ele alınabilmektedir.

İş sağlığı problemleri de dikkate alınarak geleneksel yağlayıcılara alternatif olarak son yıllarda ham veya kimyasal olarak modifiye edilmiş bitkisel yağlayıcılar, iyonik sıvılar ve nano yağlayıcılar geliştirilmiştir (Osama ve Singh, 2017).

\subsection{Saf (Düz, Pür, Susuz) Yağlar}

$\mathrm{Bu}$ yağlar temel olarak ham yağ yani mineral yağlardır. Geniş bir kullanım alanına sahip olan mineral yağlar ham petrolün rafine edilmesiyle elde edilen hidrokarbon bileşikleridir. Bu yağların özellikleri hidrokarbon zincirinin uzunluğuna, yapısına ve rafinasyon derecesine bağlıdır. Mineral yağlar saf olarak veya genellikle klor ve kükürt bazlı aşırı basınç (EP) katık maddeleri ile karışım halinde kullanılır. Bu yağların soğutma özellikleri iyi olmamasına rağmen yağlama ve korozyona dayanım özellikleri iyidir (Wisley ark., 2001). 
Hidrokarbon oranı yüksek olduğundan mineral yağların kanserojen etkileri vardır. Rafine edilmiş mineral yăg içindeki bileşiklerin oranları, ham yağın kökenine ve rafinasyon metotlarına bağlıdır. Kimyasal yapılarına göre parafinik, naftenik veya aromatik olarak tanımlanabilirler. Yüksek oranda aromatik hidrokarbonlar içeren yağlar insan sağlığına zararları dolayısıyla metal işleme sıvısı olarak kullanılmazlar (Gündoğdu, 2006)

Çok daha zor uygulamalar için kullanılabilen saf yağlar ıslanma ajanı ve sülfür, klorin, fosfor gibi bileşenler ihtiva eden EP katıkları içerebilir. Bu yağların en büyük avantajı pas koruyuculuğu, kolay bakım yapılabilmesi, uzun ömürlü yağ haznesi, bakteri gelişimine izin vermemesidir. En büyük dezavantajlarından biri olarak iş parçası üzerinde yağlı yüzey tabakası bırakması ve temizlenmesi zor olması sebebiyle başka temizleme solventlerinin kullanımına ihtiyaç duyulmasıdır (Petroyağ ve Kimyasalları San. ve Tic. A.Ş., 2015). Şekil 1'de saf yağın operasyon noktasında ortaya çıkan görüntüsü yer almaktadır:

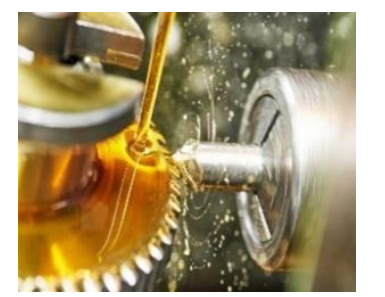

Şekil 1. Saf Yağlar (Straight Oils)

\section{2. Çözünür (Su ile Karışabilen, Emülsiyon) Yağlar}

Suda çözünen yağlar genellikle \%60-90 mineral yağ, emülgatörler ve katkılardan oluşur. Endüstride "bor yağı" olarak da bilinen bu emülsiyonlar, yağ ve suyun iyi karışması sebebiyle iyi yağlayıcılık ve soğutma özelliğine sahiptirler. Bu yağlar çeşitli demirli ve demir içermeyen hafif ve orta kademeli operasyonlarda kullanılmak için uygundur. EP katığıyla iyileştirilince, ağır kademeli operasyonlarda kullanılabilirler. Bu yağların en büyük dezavantajı, pas kontrol problemleri, bakteri ile döküntü yağlarda oluşan kontaminasyondan dolayı bayatlama ve buharlaşma kaybıdır (Petroyağ ve Kimyasalları San. ve Tic. A.Ş., 2015).

Bitkisel ve hayvansal yağların ya da esterlerin ilavesi emülsiyonların yağlayıcılık özelliğini arttırır. Bazı özel taşlama operasyonları ve ağır işlemlerde kullanılmazlar. Bunu mümkün kılmak amacıyla kükürt, klor, fosfor ve organik yağlar gibi katkılar ilave edilir. Ayrıca, köpük önleyici maddeler, bakteri oluşumunu önleyici maddeler, koku giderici maddeler vb. ilave edilebilir (Kavuncu, 1975).

Bor yağları su ile karıştırıldığında Şekil 2'de gösterildiği gibi süt rengini alır. Açık mavi ya da buna benzer mavimtırak kurşuni bir renk oluştuğunda bor yağı bozulmuş demektir ve bunun sonucunda rahatsız edici bir koku ortaya çıkarak yağ ile su birbirinden ayrılır. Bozulmanın nedeni bor yağı içerisindeki bakterilerdir. Havasız ortamda yaşayan bu bakterilerin gelişmesi ve bor yağının bozulması ile aşağıdaki durumlar ortaya çıkar:

- Bor yağının içerisine karışan talaş parçacıkları ile emülsiyon arasındaki kimyasal reaksiyonlar sonucu hidrojen açığa çıkar ve bu hidrojen bakterilerin gelişmesini hızlandırır.

- Emülsiyonun pH değeri azaldıkça bakteriler de artar.

- Bakterilerin gelişmesinin en hızlı olduğu sıcaklık $26^{\circ} \mathrm{C}$ ila $38^{\circ} \mathrm{C}$ arasındadır (Kavuncu, 1975).

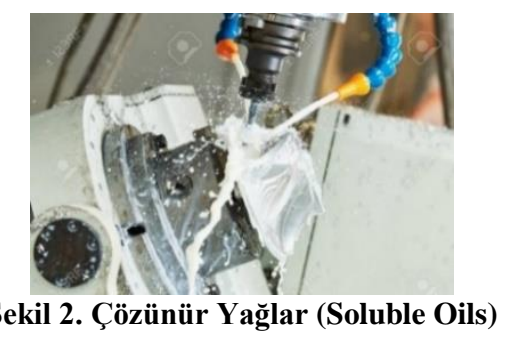

\subsection{Sentetik Yağlar}

Laboratuvar ortamında elde edilen bu yağlar yüksek soğutma kapasitesi, çok iyi nemlilik, yüksek yağlayıcılık, mükemmel korozyon önleme, kolay bakım özellikleri ile tasarlanmıştır. Bu sıvıların çoğu aminler, nitritler, nitratlar, fosfatlar, boratlar, sabun, sslatma ajanları, fosfor, klor ve sülfür bileşikleri, glikoller, mikrop öldürücüler gibi kimyasallar içermektedir. İçerdikleri yüksek orandaki çeşitli kimyasallar cildi tahriş edebilmektedir. Örneğin; aminler, tahriş edici dermatite yol açmaktadır. Diğer temel dezavantajları kaçak yağlar ile emülsiyon yapabilir olması, köpürme ve kirliliktir (Petroyağ ve Kimyasalları San. ve Tic. A.Ş., 2015; Kuram,2009). 
Su ile birlikte görüntüsü Şekil 3’te gösterildiği gibi yarı saydamdan opak hale doğru değişir. Bu yağlar, hafif yüklü taşlama işleminden yüksek basıncın izin verdiği zorlu kesme işlemi gibi ağır yüklü talaşlı imalata kadar çok çeşitli alanlarda kullanılır. Mineral yağlara göre daha az kullanılmasına karşın istenilen duruma göre kimyasal özelliklerinin değiştirilebilmesi büyük bir avantajdır. Üretim maliyetleri yüksektir (Petroyağ ve Kimyasalları San. ve Tic. A.Ş., 2015).

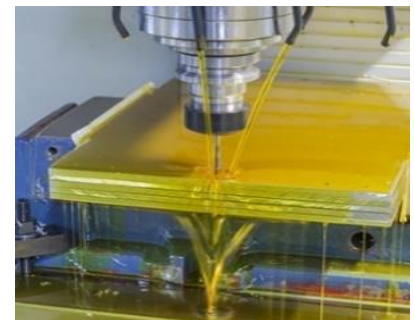

Şekil 3. Sentetik Yağlar (Synthetic Oils) (Petroyağ ve Kimyasalları San. ve Tic. A.Ş., 2015)

\subsection{Yarı Sentetik Yağlar}

Sentetik sıvılar sert suda daha kararlı oldukları için daha iyi soğutma ve mikrobiyal bozulmalara karşı yüksek dayanım sağlamaktadırlar. Fakat suda çözünebilen yağlar sentetik sıvılara göre bakteri üremesine karşı daha zayıf olmalarına rağmen, daha iyi yağlayıcılık ve geri kazanım özelliklerine sahiptirler. Bu sebepler yarı sentetik sıvıların geliştirilmesine yol açmıştır. Su bazlı olan yarı sentetik sıvılar, kararlı bir mikro emülsiyon sistemi oluşturmak amacıyla, yağ bazlı katkıların su içinde emülsiye edilmesiyle meydana gelirler. Yarı sentetik sıvılar, suda çözünebilen yağ teknolojisinin avantajlarıyla birlikte, sentetik sıvıların bakterilere karşı yüksek dayanım ve uzun tank ömrü özelliklerine sahiptirler (Gündoğdu, 2006).

Bunlar temel olarak suda çözünen yağların ve sentetiklerin karışımdır, su ile seyreltilebilir konsantre içinde \%230 oranında mineral yağ, emülgatör ve sudan oluşan küçük dispersiyonlar içermektedirler. Yüksek emülgatör içeriğinden dolayı genellikle yarı saydam emülsiyon oluşturur. Bu yağların avantajı çok iyi soğutma ve nemlilik sağlama özelliği, suda çözünen yağlardan daha iyi temizleme özelliği, daha uzun raf ömrü ve mükemmel korumadır. En büyük problemleri, sert su ile düşük kararlılıkları, yüksek köpük oluşumu ve çözünen yağlardan daha düşük yağlayıcılık özelliğine sahip olmalarıdır (Petroyağ ve Kimyasalları San. ve Tic. A.Ş., 2015).

\section{Metal İşleme Sıvılarına İliş̧kin Tehlikelerin Tanımlanmasında Dikkat Edilecek Hususlar}

Talaşlı imalat yapılan birçok sektörde işin doğası gereği çeşitli metal işleme sıvıları kullanılmaktadır. Bu kimyasallara ilişkin tehlikelerin belirlenememesi durumunda ise çalışan sağlı̆̆ını olumsuz etkileyecek riskler ortaya çıkmaktadır. Bu riskleri ortadan kaldırmak veya en aza indirebilmek için tehlikeli kimyasallara ilişkin güncel veriler titizlikte toplanmalı ve kimyasal maruziyeti risk değerlendirmesinde tüm yönleriyle ele alınmalıdır.

Soğutma sıvıları piyasada çeşitli kimyasal kompozisyonlarda ve kalitelerde bulunabilmektedir. İşyerinde kullanılması amacıyla satın alınan soğutma sıvılarına ilişkin bilgiler öncelikle tedarikçiden sağlanmalıdır. Kimyasal Maddelerle Çalışmalarda Sağlık ve Güvenlik Önlemleri Hakkında Yönetmelik (KMÇSGÖHY) 9/3. maddesinde tedarikçi, işverenin talep etmesi halinde akışkana ilişkin güncel Türkçe güvenlik bilgi formu ve akışkanın tehlike ve zararları hakkında bir dizi bilgiyi vermekle yükümlü kılınmıştır (Çalışma ve Sosyal Güvenlik Bakanlığı, 2013). Bu bağlamda son kullanıcıya yönelik, varsa kimyasalların meri mevzuatta yer alan özel risk değerlendirmelerinin de temin edilmesi önemlidir.

ABD'de Occupational Safety and Health Administration (OSHA), metal işleme sıvıları hakkında yayımlandı̆̆ en iyi uygulamalar el kitabında, tedarikçilerin sıvıların güvenlik ve sağlık bilgilerini güncel güvenlik bilgi formları ile son kullanıcıya temin etmesinin yanı sıra sağlık, kimyasal veya sıvı yönetim programı, müşsteri destek programı ve sağl1k, güvenlik ve çevre desteğini kapsayan ürün koruma programı sağlamak gibi ilave destek verebileceğini belirtmiştir (Occupational Safety and Health Administration (OSHA), 1999).

Metal işleme sıvılarının kullanımında temel sorunlar bakteri ve mantar oluşumuna mahal verebilecek kirliliklerin varlığı ve kesme takımı ile parça işlenirken yağın aşırı ısınması sonucu polisiklik aromatik hidrokarbonlar (PAH) dahil sislerin oluşmasıdır. Metal işleme sıvıları ile çalışmada temel hedef bu sıvıların çalışma ömürlerini mümkün olduğunca uzatmaktır. Soğutma sıvilarının erken bozulmalarının temel nedenlerinden biri mikrobiyal kirliliktir. Soğutma sıvılarının kimyasal bileşimleri belirli işlevleri yerine getirmek amaçlandığından karmaşıktır. Açık alanda ve ortam sıcaklığındaki sistemlerde bu bileşimler bakteri ve fungi gibi mikroplar için besin kaynağı olabilmektedir. Bu mikroplardan kaynaklı kirlilik hem yağın erken bozulmasına hem de çalışanların sağlık ve güvenlikleri için tehdit oluşturmaktadır (Frank,2011; Canter,2109). 
Su ile karışabilen metal işleme sıvılarından çoğu bileşimlerinde mikroskobik organizmaları öldüren ve kendisini mikrobiyal bozulmadan koruyan kimyasal bir biyosit içermesinin yanı sıra kullanım sürecinde de yağ haznesine biyosit ilave edilebilmektedir. Biyosit konsantrasyonun fazlası çalışanlarda cilt veya solunum yolu irritasyonu ve hassasiyetine neden olabilir. Mikrobiyal büyüme ağırlıkça \%0.15 biyosit eklenerek azaltılır. Bu biyositler antimikrobiyal olmalarına rağmen çalışan sağlığı için kanserojen olan formaldehit salgılarlar (Nune ve Chaganti, 2019).

Metal işleme sıvılarının seçiminde $\mathrm{PAH}$, klorlu parafinler, alkanolaminler, nitritler ve formaldehit salan biyositler içeren yağlar gibi potansiyel kanserojen bileşenlerden sakınılmalıdır. Etanolamin içeren metal işleme sıvılarına nitrit içeren malzemelerin eklenmesi engellenerek nitrozamin oluşma potansiyeli azaltılmalıdır. (The National Institute for Occupational Safety and Health (NIOSH), 1998). Klorlu parafinler, düşük uçuculuğa ve yüksek parlama noktalarına sahip yanıcı olmayan bileşikler olması sebebiyle güvenli kabul edilir ve metal işleme endüstrisinde yaygın olarak kullanılmaktadır (Schinkel ve Lehner, 2018).

Metal işleme sıvılarının kullanım ömürleri boyunca yakından ve sistematik olarak izlenilmesi ortaya çıkan belirtilerin çalışan sağlığı ve güvenliği yönünden değerlendirilmesi önem teşkil etmektedir. Bu değerlendirme sonucunda kullanımın sonlandırılması dâhil ilave tedbirlerin yerine getirilmesi sürdürülebilir güvenli bir kullanım için elzemdir. Kullanım sürecinde ortaya çıkan aşağıda açıklanacak durumlar iş sağlığı ve güvenliği yönünden tehlikelerin belirlenmesinde kayda değer bilgi ve belirtiler sağlayacaktır:

\section{a) Düşük Yă̆ Haznesi Seviyesi}

Haznenin dolu halinin \%30'unun altı düşük yă̆ seviyesini göstermektedir. Bu durum metal işleme sıvısının kaybı veya su buharlaşması ile ortaya çıkabilir. Bu durumlarda konsantrasyonu kontrol etmek amacıyla yoğunluk artmışsa, uygun konsantrasyona gelene kadar su eklenmelidir, şayet konsantrasyon değişmemişse akışkanın sızıntı sonucu azaldığı anlaşılmalıdır. Nihayetinde düşük yağ haznesinin akışkandaki kimyasalların konsantrasyonunun artmasına sebep olabileceği dikkate alınarak her vardiya başlangıcında yağ haznesinin seviyesi kontrol edilmeli ve ihtiyaç duyulan ekleme-çıkarmalar sonrasında konsantrasyonun uygunluğu teyit edilmelidir (Occupational Safety and Health Administration (OSHA), 1999).

\section{b) Anormal Görünüş}

Akışkanın rengi uygunluğu konusunda bilgi verir. Doğru koşullarda sentetik akışkanlar berrak, yarı sentetikler saydamdan süt rengine kaçan bir renkte ve su ile karışan yağlar serbest yağ katmanı bulunmayan süt beyazı görünümdedirler. Eğer akışkanda bakteri mevcudiyeti çoğunlukla renginin gri veya siyaha çalmasına, yabancı yă̆ mevcudiyeti ise sarı veya kahverengi bir renk almasına sebep olabilir. Renk solması ise akışkanın eskimiş olduğuna işaret olabilir (Occupational Safety and Health Administration (OSHA), 1999). Şekil 4'te anormal görünüşe sahip kirlenmiş bir akışkan görülmekte olup söz konusu emülsiyonda görülen bu tip kırılmaların olası nedenleri; bakteri üremesi, aşırı yabancı yağ sızıntısı, emülsiyon hazırlanmasında sert su kullanımı ve önce akışkanın sonra suyun ilavesi şeklinde ters emülsiyon yapılması olabilmektedir (Belgin Madeni Yağlar, 2019).

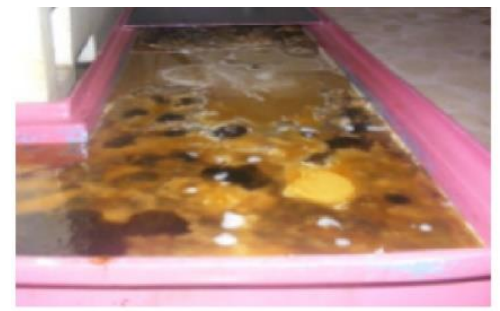

Şekil 4. Kirlenen Soğutma Haznesi (Contaminated Oil Sump) (Demir, 2009)

\section{c) $A \breve{g}_{l} r \mathrm{Koku}$}

Akışkandaki ağır koku bozulmanın yani içerisindeki mikropların Şekil 5'te görüldüğü gibi kontrolsüzce çoğalmasının sonucudur. Bu kokuya sebep olan mikroorganizmalar akışkanın buharlaşması sonucu çalışma ortamının havasına karışabilir ve bu duruma maruz kalan çalışanların sağlığında olumsuz etkilere sebep olabilir. Çalışma ortamında akışkandan yayılan güçlü bir "soyunma odası” kokusu varlığı büyük olasılıkla akışkandaki biyolojik çoğalmanın işaretidir. $\mathrm{Bu}$ durumda biyosit ile müdahale edilerek akışkanın son durumun değerlendirilmesi gereklidir. Değerlendirme sonucunda gerekiyorsa akışkan bertaraf edilmeli, akabinde yă̆ haznesi düzgünce temizlenmeli ve akışkan değiştirilmelidir (Occupational Safety and Health Administration (OSHA), 1999). 


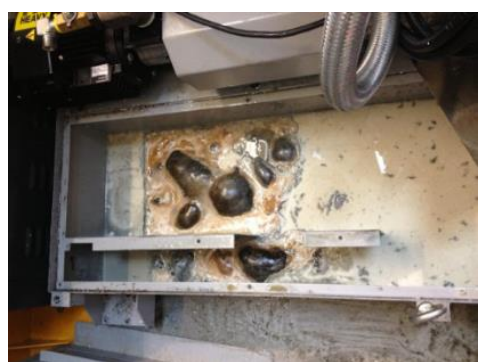

Şekil 5. Soğutma Sıvısında Mikropların Kontrolsüzce Çoğalması (Uncontrolled Growth of Micro-organisms in MWF) (Lubriserv, 2020)

\section{d) Aklşan Üstünde Yüzen Maddeler ve Yabancı Yağlar}

Şekil 6'da görüldüğü gibi akışkanda kırıntılar ve metal talaşlarının yüzmesi veya küflenme normal değildir. Bir yüzey sıyırıcı yardımıyla mümkün olduğunca akışkandan alınmaya veya dışarıya pompalanmaya çalışılmalıdır. Akışkandaki kir seviyesi (tüm askıda kalmış katılar) filtreleme sisteminin etkinliğinin göstergesidir. Bu sebeple filtreleme sistemi ve yağ sıyırıcısının periyodik kontrol ve bakımlarının yapılarak tasarlandığı şekilde çalışmalarını sağlamak elzemdir (Occupational Safety and Health Administration (OSHA), 1999).

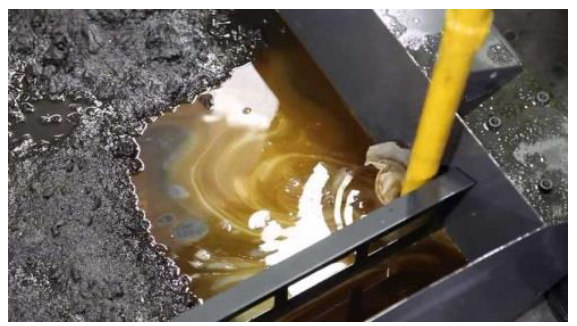

Şekil 6. Yüzey Üzerinde Görülen Yabancı Maddeler (Impurities on MWF) (Lubriserv, 2020)

Su ile karışarak seyreltilen akışkanlarda hazne tamamen yağla kaplandıysa ve makine operatörü hazne tekrar kaplanmadan önce yağın temizlenmesini 5 ila 8 saniye arasında bitiremiyorsa çok fazla yabancı yăg mevcut demektedir. Yüzeydeki yabancı yağın kaldırılması için ayırılması veya pompalanması gerekmektedir. Şekil 7'de akışkandaki yabancı yağ örnekleri görülmektedir.

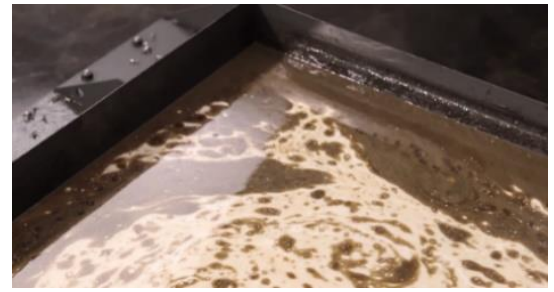

Şekil 7. Yüzey Üzerinde Görülen Yabancı Yağlar (Tramp Oils on MWF) (Lubriserv,2020)

Yabancı yağlara müdahale edilmezse bakterilerin beslenip gelişmesine uygun havasız (oksijensiz) bir alan oluşur. Bakteriler, yabancı yağ tabakasını kaldırılması oldukça zor olan bir biyokütle (biyomass) tabakasına dönüştürürler, buradan merkezi soğutma sistemine kadar ilerleyebilirler. Akışkanda bakteri oluşmasıyla beraber pH düşer ve akışkan asit banyosu haline gelerek makinanın iç aksamlarını paslandırır. Bu süreç sonunda havuzdan fena kokular gelmeye başlar ve dermatolojik hastalıklar ortaya çıkar (3-S Mühendislik, 2011).

\section{e) Aşırı Köpük}

Çok fazla köpük yumuşak su kullanımından kaynaklanabilir. Ayrıca yüksek konsantrasyon, kullanılan temizleyicilerden bulaşma veya yüzey aktif maddelerindeki dengesizlik de köpüğün kaynağı olabilir. Bunların haricinde diğer ihtimaller normalden daha küçük sistem, yoğun akış miktarları ya da akışkanın hava çıkmasına müsaade edecek kadar yeterli miktarda hareketsiz kalmaması olabilmektedir. Haznedeki akışkan seviyesi düşük de olabilir ve bu da havanın, pompanın içine çekilmesine sebep de olabilir. Şekil 8 a ve b'de hazne ve operasyon noktasındaki aşırı köpük oluşumu görülmektedir (Occupational Safety and Health Administration (OSHA), 1999). 

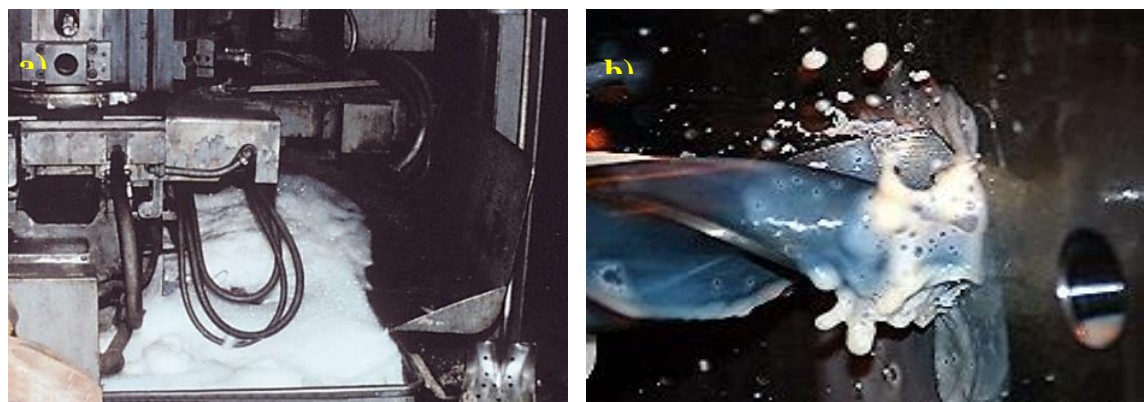

Şekil 8. Așırı Köpük Olușumu a) haznede olușan köpük (foam in sump), b) takım üzerinde olușan köpük (foam on tools) (Master Chemical Corporation,2005)

\section{f) Kirli Makineler veya Çukurlar}

Makinelerin Şekil 9'da görüldüğü gibi kirlenme durumları emülsiyonun kararsız olduğunun, akışkandaki temizleyicilerin bittiğinin, kirleticilerin akışkanda biriktiğinin, filtre bozukluğunun ya da kötü bakım ve temizlik yapıldığının belirtisi olabilir (Occupational Safety and Health Administration (OSHA), 1999).

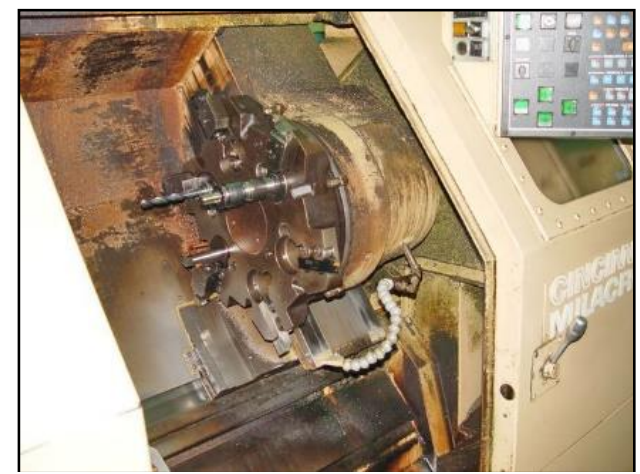

Şekil 9. Paslanmış Bir Makine (A Rusted Machine) (Master Chemical Corporation,2005)

\subsection{Maruziyet Sınır Değerleri}

Tehlikeli kimyasal maddelere maruziyete ilişkin risk değerlendirmesi verisi olarak "mesleki maruziyet sınır değerleri" KMÇSGÖHY'de açıklanmıştır. Buna göre; başka şekilde belirtilmedikçe, 8 saatlik sürede, çalışanların solunum bölgesindeki havada bulunan kimyasal madde konsantrasyonunun zaman ağırlıklı ortalamasının üst sınırı "mesleki maruziyet sınır değerini” ifade eder. Söz konusu yönetmeliğin ekinde 125 kimyasal maddeye ilişkin "TWA (Zaman Ağırlıklı Ortalama)" değeri olarak sınır değeri belirtilmiştir. Yönetmelikte mesleki maruziyete ilişkin tanımlanan bir başka ölçüt ise "STEL (Kısa Süreli Maruz Kalma Düzeyi)" değeridir ve başka bir süre belirtilmedikçe, 15 dakikalık bir süre için aşılmaması gereken maruziyet üst sınır değerini ifade etmektedir (Çalışma ve Sosyal Güvenlik Bakanlığı, 2013).

Yönetmelikte mesleki maruziyete ilişkin TWA ve STEL olarak belirtilen iki ölçüt yer almasına karşın dünyada mesleki maruziyete ilişkin çeşitli ölçütler kullanılmaktadır. Bunlardan başlıcaları şunlardır:

- LC50 (Medyan Letal Konsantrasyon): Solunum yolu ile organizmaya girerek etki gösteren gaz halindeki kimyasal bileşiklerin akut toksisite ölçüsüdür.

- MAK (Maximum Allowed Concentration): Maksimum Müsaade Edilir Konsantrasyon

- TLV-TWA (Threshold Limit Value) Eşik Limit Değer: Havada bulunmasına izin verilen, zararlı etkisi olmayan günlük ortalama konsantrasyon

- TLV-STEL (Short Term Exposure Limit): Kısa bir zaman süresince müsaade edilen düzey (genellikle 15 dakika)

- TLV-C (Ceiling): Kısa süreyle de olsa aşılmaması gereken düzey

- PEL (Permissible Exposure Limit): İzin verilen maruziyet seviyesi

- REL (Recomended Exposure Limit): Önerilen maruziyet seviyesi

- IOELVs (Indicative Occupational Exposure Limit Values): Gösterge Niteliğinde Mesleki Maruziyet Sinır Değerleri

- BOELVs (Binding Occupational Exposure Limit Values): Bağlayıcı Mesleki Maruziyet Sinır Değerleri

NIOSH'un görüşüne göre, çoğu talaş kaldırma işlemlerinde, metal işleme sıvılarının aerosolüne maruziyetlerin $0,4 \mathrm{mg} / \mathrm{m}^{3}$ veya daha düşük değer ile sınırlandırılması teknolojik olarak uygundur (The National Institute for 
Occupational Safety and Health (NIOSH), 1998). Dünya'nın çeşitli ülkelerinde yasal maruziyet sınır değerlerinin olabildiğince altında çalışılması önemle tavsiye edilmekte olup uygulanan bazı maruziyet limit değerleri Tablo 3 'te özetlenmiştir.

Tablo 3. Metal İşleme Sıvıları Maruziyet Limit Değerleri (Occupational Exposure Limit Values of MWF)

\begin{tabular}{|l|l|l|l|l|l|l|}
\hline Madde & $\begin{array}{l}\text { OSHA Standardı- } \\
\text { PEL (TWA) }\end{array}$ & $\begin{array}{l}\text { NIOSH } \\
\text { Standardı- } \\
\text { REL } \\
\text { (TWA) }\end{array}$ & $\begin{array}{l}\text { ACGIH-TLV } \\
\text { (TWA) }\end{array}$ & $\begin{array}{l}\text { HSE-WEL } \\
\text { (TWA) }\end{array}$ & Almanya & Türkiye \\
\hline $\begin{array}{l}\text { Mineral Yağ Buharı } \\
\text { (Toplam Miktar) }\end{array}$ & $5 \mathrm{mg} / \mathrm{m}^{3}$ & $\begin{array}{l}0,5 \mathrm{mg} / \mathrm{m}^{3} \\
\left(0,4 \mathrm{mg} / \mathrm{m}^{3}\right)^{*}\end{array}$ & $\left.-5 \mathrm{mg} / \mathrm{m}^{3}\right)^{* *}$ & $\left(3 \mathrm{mg}^{\prime} / \mathrm{m}^{3}\right)^{* * *}$ & $10 \mathrm{mg} / \mathrm{m}^{3}$ & - \\
\hline $\begin{array}{l}\text { Diğer Metal İşlem } \\
\text { Akıskanları } \\
\text { (PNOC****) }\end{array}$ & $15 \mathrm{mg} / \mathrm{m}^{3}$ & - & - & - & - \\
\hline
\end{tabular}

*Torasik Partül Miktarı: Gırtlak ötesine nüfuz eden partikül oranı

**Solunabilir (Inhalable) Partikül Miktarı: Burun ve boğazda tutulan partikül oranı

***Metal işleme sektörü çalışanlarında görülen hastalıklar sebebiyle söz konusu solunabilir değer 2005 yılında geri çekilmiş olup yeni bir sınır değerinin belirlenmesi için çalışmalar yapılmaktadır.

****PNOC: Başka Türlü Sınıflandırılmayan Partiküller

Ülkemizde doğrudan metal işleme akışkanlarına ilişkin bir maruziyet sınır değer düzenlemesi olmamakla beraber bu sıvıların temel bileşenlerinden olan mineral yă̆ buharları için de sınır değeri mevzuatta yer almamaktadır. NIOSH, maruziyet ölçümlerinin en azından her yıl düzenli olarak yapılmasını tavsiye etmektedir. Ülkemizde ise risk değerlendirmesi yapılırken ve yenilenirken gereken durumlarda maruziyet ölçümü yapılması zorunlu kılınmıştır (Çalışma ve Sosyal Güvenlik Bakanlığı, 2013).

\subsection{Metal İşleme Sıvılarına İlişkin Tehlikelerden Kaynaklanabilecek Sağlık Riskleri}

Metal işleme sıvıları kontamine (kirlenmiş) maddelerinin, spreylerinin veya buharlarının cilde temasıyla ya da teneffüs edilen sis (buhar) ve aerosollerinin solunmasıyla sağlığa olumsuz etkileri olabilmektedir. Metal işleme sıvılarına cilt ve hava yoluyla maruziyet cildin, gözlerin, akciğerlerin, boğazın ve burnun tahrişini içeren sağlık sorunlarını kapsamaktadır. Dermatit, akne, astım, hipersensitivite pnömonisi (HP), üst solunum yolu tahrişi ve çeşitli kanserler metal işleme sıvılarına maruziyetle ilişkilendirilmiştir (The National Institute for Occupational Safety and Health (NIOSH), 1998). Sağlık problemlerinin ciddiyeti akışkanın çeşidi, kirlenmenin tipi ve derecesi ve maruziyetin düzeyi ve süresi gibi çeşitli faktörlere bağlıdır (Occupational Safety and Health Administration (OSHA), 1999).

\subsubsection{Cilt Hastalıkları}

Çalışanların, özellikle akışkanla doğrudan temas eden operatörlerin ciltlerinde tahriş olması akışkanın bazı olumsuz özelliklerinin sorgulanmasını gerekli kılar. Bunlar; konsantrasyon yüksekliği, yüksek alkalilik, metal kirliliği, kararsız emülsiyon olabilir. Şekil 10'da gösterilen tipik bir cilt tahrişinin oluşumuna akışkandan kaynaklı bu faktörler dışında hava değişikliği, kötü kişisel hijyen ve çalışma alışkanlıkları, sert el sabunlarının kullanımı, kirli kıyafet kullanımı vb. faktörler de etki edebilir (Occupational Safety and Health Administration (OSHA), 1999).

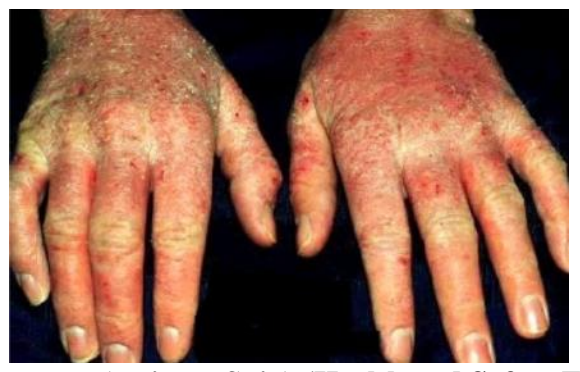

Şekil 10. Tahriş Olmuş Eller (Irriated Skin) (Health and Safety Executive(HSE), 2007) 
Çalışanlarda cilt tahrişinin görülmesi tehlikenin artık riske dönüşmesini ifade etse de daha dermatitin kabul edilebilir düzeyinin işyeri hekimlerince belirlenerek daha ciddi sağlık riskleri (cilt kanseri, solunum yolu hastalıkları, kanserler vb.) için alınacak aksiyonların belirlenmesinde veri olarak değerlendirilebilecektir.

Çalışanların eldiven ve önlük gibi kişisel koruyucu donanımları kullanmaksızın ellerini akışkana içerisine daldırdıklarında veya akışkanla kaplanmış parçaları, takımları ve araç-gereçleri elleriyle tuttuklarında ciltle teması meydana gelir. Bu temas aynı zamanda makinede korumanın olmadığ ya da yetersiz olduğu durumlarda sıvı sıçraması olarak da ortaya çıkabilir. Kontakt dermatit ve akne metal işleme sıvılarıyla ilgili ortaya çıkan cilt hastalıklarıdır (Occupational Safety and Health Administration (OSHA), 1999).

Kontakt dermatit, metal işleme sıvılarıyla ilgili en sık bildirilen cilt hastalığıdır. Kontakt dermatiti olan kişilerde kaşıntılı deri ve kurdeşen (ürtiker), çatlaklar, kızarıklık, su toplaması ve kabarcıklar gibi belirtiler görünür. Alerjik dermatit ve irritant dermatit olmak üzere iki çeşit kontakt dermatit vardır. İrritant kontakt dermatitte kurdeşen tahriş edici maddenin temas ettiği kısmı kapsar. Alerjik kontakt dermatitte ise kurdeşen tahriş edici maddenin doğrudan temas ettiği kısımdan başka bölgelere de yayılabilir. Yağlanmış kıyafetlerle temas eden ön kollarda, kalçalarda, bacaklarda vb. vücudun çeşitli kısımlarında sarı çıbanlar ile kırmızı şişler görülebilir (Occupational Safety and Health Administration (OSHA), 1999). Metal işleme sivilarına maruz kalan çalışanların \%14 ila 67 arasında dermatit gelişmesi riski vardır (The National Institute for Occupational Safety and Health (NIOSH), 1998). Şekil 11'de tipik bir kontakt dermatit görülmektedir.

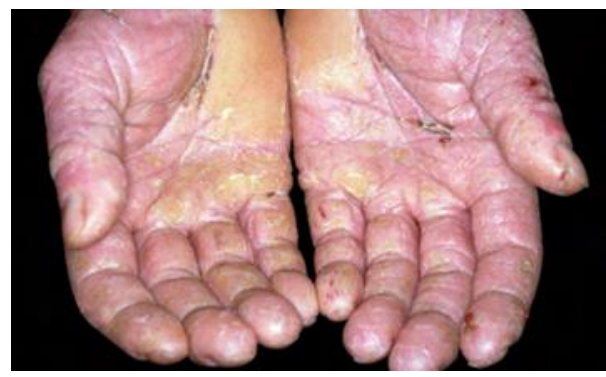

Şekil 11. Dermatit Hastalığında Ellerde Görülen Kuru Pullanma ve Çatlaklar (Cracks and Flaking Symptoms of Dermatits) (United Kingdom Lubricants Association (UKLA), 2018)

Mesleki dermatitin en sık nedenlerinden biri yağlardır. Yağların biyolojik kirliliği altta yatan deri hastalıkları alevlenmesinde önemli bir etkendir. Metal işleme sıvıları bakteri ve mantarlarla kolayca kontamine olur. Mineral yağı içeren su ile karışmayan metal işleme sıvılarıyla etkileşmenin tekrarlanması deri kanserine de sebep olabilir (İş Sağllğı ve Güvenliği Genel Müdürlüğü,2013).

Metal işleme operasyonlarında kontakt dermatite neden olabilecek bazı faktörler şöyle sıralanabilir; metal işleme sıvıları ile kontamine olmuş giysiler, maruziyet sonrası derinin yıkanmaması gibi zayıf kişisel hijyen alışkanlıkları, kötü temizlik uygulamaları, tavsiye edilen metal işleme sıvısı konsantrasyonlarından daha yüksek akışkan, cildin doğal yağlarını kaldırabilen yüksek alkalinite, yağ çözücüler, temizleyiciler veya pas önleyiciler gibi metal işleme yardımcı maddeleri, sıvı içinde bulunan ve cildi aşındırabilecek metal talaşı, akışkan ile uzun süreli temas, hidrolik sıvıları, dişli veya mil yağları, yağlama yağları, gres gib sızıntı (katışkı) yağları, aşındırıcı sabunlar veya aşırı sıcak veya soğuk su ile el yıkama, kış kuruluğu gibi mevsimsel koşullar, diğer kirleticiler (yağ bazlı bir sistemdeki su vb.) (Occupational Safety and Health Administration (OSHA), 1999). Metal parçacıkları ve metal talaşlarının sebep olabileceği küçük kesikler de akışkanın cilde daha kolay nüfuz etmesine yardım eder ve tahriş edici (irritant) dermatiti kolaylaştırır (Industries, 2001).

Su bazlı metal işleme sıvıları (çözünür, sentetik ve yarı sentetik) ile çalışanlar kontakt dermatitin açısından en fazla risk altında bulunanlarken, saf yağlar genellikle sivilcelerle karakterize edilen akneye benzer rahatsızlıklarla ilişkilendirilir (Occupational Safety and Health Administration (OSHA), 1999).

Alerjik dermatit, tahriş edici dermatite nazaran genellikle daha az görülmektedir. Akışkan içerisindeki katkı maddeleri (aminler, antikorozifler, koruyucular gibi) bünyesi güçsüz olanlar da alerjik etkileşimlere neden olur ve derininin tahriş olmasıyla beraber bu katkı maddeleri derinin koruyucu tabakasına zarar vererek rahatlıkla içeriye nüfuz ederler. Sıklıkla parmaklarda ve ellerde oluşan yaralar, tahriş edici dermatitte görülen yararlara benzer özellikler göstermekle beraber çalışanlar akışkana maruziyetin olduğu ortamdan uzaklaştırılmadan tedavi edilemezler. Tahriş edici dermatitten farklı olarak tahrişe sebep olan maddenin temas ettiği bölgenin dışına da yayilirlar (Industries, 2001).

Kullanılan kesme sıvıları kadar, yapılan iş tipinin de rahatsılılklara etkisi büyüktür. Örneğin; broşlama işleminde daha fazla yağlama gerekir ve burada kullanılan yağlar $\mathrm{Cl}$ ve yüksek basınç EP katkıları içerdiklerinden daha 
fazla tahriş edicidir. Taşlama ve torna tezgahlarında da cilt hastalıklarına rastlanma oranı daha yüksektir (Yücel ark., 2011).

Cilt hastalığının gelişmesini önlemeye çalışmak ve erkenden tedavi etmek önemlidir. Çünkü tedavi edilmeyen dermatit daha ciddi komplikasyonlara yol açabilmektedir (The National Institute for Occupational Safety and Health (NIOSH), 1998).

\subsubsection{Solunumla İlgili Rahatsızlıklar}

Metal işleme sıvılarının aerosollerine maruziyet, gögüste irritasyon (tahriş) ve sıkışma şikâyetlerine neden olabilir. Tahrişe neden olan faktörler; akışkanın kesim bölgesine uygun olmayan şekilde dağıtılması, katkı maddelerinin hatalı kullanımı, yüksek soğutma konsantrasyonu, küçük bir alanda yoğun makine kullanımı, yetersiz veya kötü dizayn edilmiş mahfazalar ve sis (buhar) toplayıcıları, mikrobik kontrol kaybı, fabrikanın kötü genel havalandırması, yetersiz taze hava hızları ve talaşlı şekillendirme işlemleri olmasa bile akışkan kanallarının keskin dönüşler yaptığı alanlarda mevcut yüksek sis konsantrasyonları olabilir.

Metal işleme sıvılarının buhar ve aerosollerinin solukla içeri çekilmesi akciğerleri, boğazı (yutak ve gırtlak) ve burnu tahriş edebilir. Boğaz ağrısı, sulu kaşıntılı kırmızı gözler, burun akıntısı ve kanaması, öksürük, hırıltılı solunum, artan balgam üretimi, nefes darlığı ve diğer nezleye benzer belirtiler semptomlarında bazılarıdır. Bu semptomlar; akut hava yolu tahrişi, astım (geri dönüşümlü havayolu obstrüksiyonu), kronik bronşit, kronik olarak bozulmuş akciğer fonksiyonu ve hipersensitivite pnömonisi gibi solunum durumlarına ilişkin işaretler verir. Solunum yolu tahrişi semptomları oluştuğunda, hastalığın belirli akışkan bileşenlerinden mi, kullanımdaki akışkanın kirlenmesinden mi yahut mikrobiyal büyüme veya parçalanma ürünlerinden mi veya bu faktörlerin bileşiminden mi olduğu açık değildir (Occupational Safety and Health Administration (OSHA), 1999).

Metal işleme sıvılarına maruziyet astımla ilişkilendirmiştir. Astımda, akciğerin hava yolları iltihaplanır ve akciğere hava giriş ve çıkışını azalmasına sebep olur. Bir astım atağı süresince, bu hava yolları şişer, kasılır ve mukus ile dolar, hava akış azalır ve nihayetinde nefes darlığına ve hırıltılı bir ses oluşur. Metal işleme sıvılarının birçok bileşeni, katkıları ve kirleticileri yeni ortaya çıkmış bir astımı başlatabilir, önceden var olan astımı şiddetlendirebilir ve astımı olmayan çalışanların hava yollarını tahriş edebilir (Occupational Safety and Health Administration (OSHA), 1999).

Kronik bronşit rahatsızlığı, balgamlı öksürük ve kronik öksürük ile karakterizedir. Balgam, akciğerlere giren ve çıkan hava arasına girebilir. Bu durum da akciğer fonksiyonundaki düşüşü hızlandırır ve sonucunda kalp ve akciğer fonksiyon hasarına yol açabilir (Occupational Safety and Health Administration (OSHA), 1999).

Hipersensitivite Pnömonisi (HP) ciddi bir akciğer rahatsızlığıdır. Son HP salgınları su bazlı metal işleme sıvılarının (çözünür, sentetik ve yarı sentetik) aerosolleriyle özellikle sıvı içerisindeki kirleticiler ve katkılarla ilişkilendirilmiştir (Occupational Safety and Health Administration (OSHA), 1999). Kısa dönemde HP öksürük, nefes darlığı ve nezle benzeri semptomlarla (ateş, titreme, kas ağrıları ve bitkinlik) karakterizedir. Tekrarlı maruziyeti izleyen kronik faz kalıcı akciğer rahatsızlı̆̆ıyla ilişkilendiren akciğer skarlaşmasıyla karakterizedir (Occupational Safety and Health Administration (OSHA), 1999). HP, mikrobiyal ürünlere maruz kalmanın neden olabileceği alerjik tipte bir reaksiyondur. HP, titreme, ateş, nefes darlığı ve derin bir öksürük ile kendini gösterir. Tedavi edilmezse, geri dönüşümsüz akciğer hasarına yol açabilir (Canadian Centre for Occupational Health and Safety, 2020).

Solunum problemlerinin belirli sıvı bileşenleri, kirleticiler, mikrobiyal büyüme veya bozulma ürünleri veya bu faktörlerin bir kombinasyonundan kaynaklanıp kaynaklanmadığı net değildir. Örneğin, metal işleme sıvısı kaynaklı astım, sentetik metal işleme sıvılarıyla daha tutarlı bir şekilde rapor edilir ancak çözünür ve düz sıvılarla da ortaya çıkabilmektedir. Yine, maruziyetin şiddeti makineye yakınlık ve operasyonların yüksek takım hızları ve derin kesimler içerip içermediğine, makinenin kapalı olup olmadığına, havalandırma ekipmanının düzgün çalışıp çalışmadığına bağlıdır. Yüksek basınç veya aşırı sıvı uygulaması, sıvının kirlenmesi (yabancı, döküntü yağ), yanlış sıvı seçimi ve yetersiz bakım da daha yüksek maruziyete neden olacaktır (Canadian Centre for Occupational Health and Safety, 2020).

Laboratuvar simülasyon testleri metal işleme sıvı türleri arasında aeroloizasyon oranında (havaya karışma) belirgin bir fark olmadığını göstermiştir. Ancak saha araştırmaları çözünebilen metal işleme sıvılarında maruziyetin daha fazla olduğunu göstermiştir (Gorny \& Szponar, 2004).

\subsubsection{Kanser}

Bazı çalışmalar metal işleme sıvıları ile rektum, pankreas, gırtlak, cilt, testis (skrotum) ve mesane kanseri ve benzerleri arasında bir bağlantı ortaya koymuştur (The National Institute for Occupational Safety and Health (NIOSH), 1998). Metal işleme sıvılarıyla bağlantılı kanser etkileri maruziyetten yıllar sonrasına kadar ortaya belirginleşmediğinden yapılan çalışmalarında onlarca yıl önce akışkanlara maruziyeti bulunan çalışanların sağlık 
geçmişlerinden yararlanılmıştır. Hava ile taşınabilir metal işleme sıvısı konsantrasyonları 1970-80’lerde günümüzden çok daha fazlaydı. Akışkanların kompozisyonları yıllar süresince önemli ölçüde değişti şöyle ki 1985'e kadar kullanımda olan ve içerilerinde nitrit, hafif rafine edilmiş petrol yağları ve diğer kimyasalları 1985 'ten itibaren sağlık endişeleri sebebiyle kullanımdan kaldırılmıştır (Occupational Safety and Health Administration (OSHA), 1999).

Metal işleme sıvıları ile ortaya çıkan cilt hastalıklarının ilerlemiş hali cilt kanseridir. Rafine edilmemiş mineral yağların cilt kanserine neden oldukları görülmüştür. Ayrıca yağla ıslanmış bez parçaları ve iş elbiseleri ile uzun süreli temas da kansere neden olabilmektedir. Şekil 12'de farklı tipteki cilt kanserleri görülmektedir (Yücel ark., 2011).

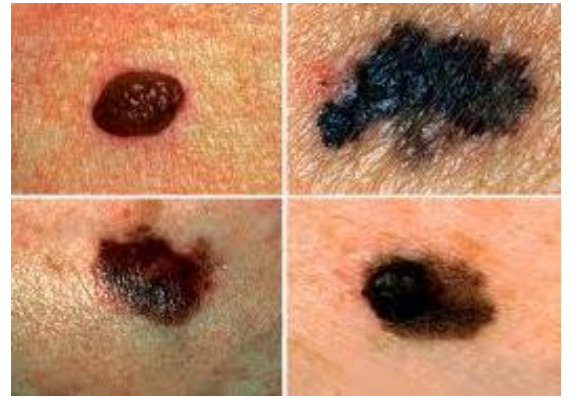

Şekil 12. Cilt Kanseri Tipleri (Skin Cancer Types) (Yücel ark., 2011)

\subsection{Metal İşleme Sıvıları ile Çalışmalarda Alınması Gereken Önlemler}

KMÇSGÖHY madde 7/1'de bir dizi önlemlerle çalışanların sağlık ve güvenliğine yönelik risklerin ortadan kaldırılması veya en az düzeye indirilmesi istenmiştir. Bu önlemler; işyeri organizasyonu, tehlikeli kimyasala maruz kalacak çalışan sayısının, madde miktarının ve süresinin azaltılmasını, çalışma alanının düzenlenmesi ve temizliğini, çalışanların kişisel temizliğini sağlayabilmesini, atık ve artıklar için uygun işleme, kullanma, taşıma ve depolama düzenlemelerini ve son olarak ikame yöntemi uygulanmasını kapsamaktadır.

İkame, tehlikeli kimyasalın yerine tehlikesiz veya daha az tehlikeli olanın kullanılmasıdır. Mezkûr yönetmeliğin aynı maddesinde, yapılan işin özelliği nedeniyle ikame yöntemi kullanılamıyorsa, risk değerlendirmesi sonucuna göre ve öncelik sırasıyla uygun proses ve mühendislik kontrol sistemleri, yeterli havalandırma sistem ve kişisel koruma kapsamında tedbirler alınarak riskin azaltılması istenmiştir (Çalışma ve Sosyal Güvenlik Bakanlığı, 2013).

Yönetmeliğin aynı maddesinin I bendinde "Mesleki maruziyet sınır değerlerinin aşıldığı her durumda, işveren bu durumun en kısa sürede giderilmesi için koruyucu ve önleyici tedbirleri alır." denilmiştir. Bu maddede maruziyet ölçüm sonucunun işverenin önlem alma noktasında harekete geçmesinde referans olabileceğinin düzenlendiği görülmektedir. Ancak bu noktada İş Ekipmanlarının Kullanımında Sağlık ve Güvenlik Şartları Yönetmeliği Ek1: 2.5.1. maddesinde "Gaz, buhar, sıvı veya toz çıkarma tehlikesi olan iş ekipmanları, bunları kaynağında tutacak veya çekecek uygun sistemlerle donatılır." amir hükmü dikkate alındığında şayet ekipmanın kendisi ve bütünleşik aksamları dâhil bir emisyona sebep veriyorsa ölçüm sonuçlarının referans alınmasından ziyade çıkan dumanı kaynağında tutacak havalandırma veya tutucu sistemlere başvurulmasının kaçınılmaz olduğu dikkate alınmalidir.

Metal işleme sıvıları ile çalışmada risklerin kontrol edilmesi kapsamında teknik ve organizasyonel önlemlerin alınması gerektiği aşikârdır. NIOSH mümkün olduğunca metal işleme sıvılarının aerosol konsantrasyonlarının önerilen maruziyet seviyesi (REL)'nin altında tutulması gerektiğini belirtmiştir. Bu seviye akışkanın aerosollerine maruz kalan çoğu işçi için koruyucu olacaktır. MWF'lere dermal maruziyet için maruz kalma limiti yoktur. Alerjik ve tahriş edici cilt reaksiyonlarını önlemek için dermal temas sınırlandırılmalıdır (Burton, 2008).

\subsubsection{Tasarım Hususları ve İşletim Prosedürleri}

Metal işleme sıvı buharlarının oluşumunun dağıtım sisteminin uygun tasarım ve işleyişiyle azaltılabileceği birçok faktör vardır. Kullanım sürecinde metal işleme sıvı buharları parçalanarak dağıldığında ince taneli sprey/buğu meydana getirir. Bu durum akışkanın dönme araç ve parçalarına uygulanması ve etkileşimi ile akışkan açık kanallarda yüksek hızda aktığında meydana gelir. Küçük buhar damlacıkları kolaylıkla hava içerisinde askıda kalır ve kapsama ve toplama araçlarından kurtulabilir (Occupational Safety and Health Administration (OSHA), 1999).

Metal işleme sıvıları dağıtım sistemi minimum miktarda akışkan buğusu oluşacak şekilde tasarlanmalıdır. Buğulanmayı azaltabilen faktörler arasında akışkanın düşük basınçta verilmesi, sıvının uygulamaya uygun hale getirilmesi, düşük yağ konsantrasyonlu akışkan formülasyonlarının kullanılması, buğu önleyici maddelerin 
kullanılması, yabancı yağlarla kontaminasyonun önlenmesi, sıvının akıș hızının en aza indirilmesi, mümkünse akışkan depolarının ve dönüş sistemlerinin kapatılması sayılabilir, akışkanın kimyasının kontrolünün sürdürülmesi ve uygun makine bakımı sayılabilir (Occupational Safety and Health Administration (OSHA), 1999).

İşlenecek parça ve kesici takımı üzerine doğrudan uygulanan yeterli ve düşük basınçlı akışkan genel itibariyle buğuyu azaltmada en etkili yoldur. Buna karşılık yüksek basınçlı akışkan buğu oluşumuna yol açtığı gibi yeterli soğutma ve yağlama da sağlamayabilir.

Sis (buhar) gidericiler de çözüm olarak dikkate alınmalıdır. Şekil.13'de endüstrideki metal işleme uygulamalarında sıkça kullanılan CNC makinelerinden kaynaklanan sis ve dumanı yakalamak ve temizlemek için tasarlanmış bir sis giderici görülmektedir (airqualityengcom). Sis gidericiler, metal işleme sıvılarından kaynaklı buharı kaynağında toplayarak bir nevi lokal havalandırma sistemi olarak görev yapmaktadır.

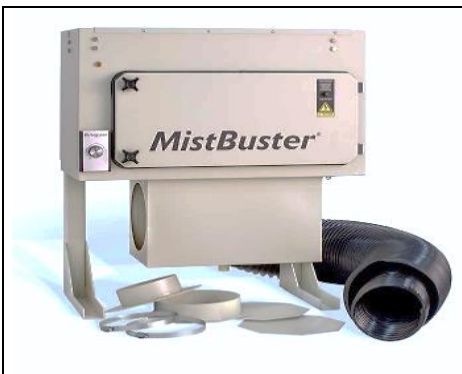

Şekil 13. Sis Giderici (Mistbuster-Mist Collector) (Air Quality Engineering, 2020)

Çalışanların akışkandan kaynaklı sise maruziyetini azaltmak için diğer temel adımlardan biri de makul olduğunca (örneğin; işlem yapılmadığı durumlarda) akışkanı kesmek ya da azaltmaktır. Böylece sadece mekanik olarak ortaya çıkan sis azalmaz aynı zamanda akışkanın bozulması ve biyositlerin oksitlenmesi azalır (Occupational Safety and Health Administration (OSHA), 1999).

Sis giderici olarak görev yapan ekipmanların filtreleme ünitelerinin belirli periyotlarda gerektirdiği bakım ve temizlik işlerinden dolayı CNC tezgâhların durması birçok işyeri tarafından istenilmeyen bir durum olması sebebiyle, filtreleme üniteleri yeterince temizlenememekte ve işlevini kaybedebilmektedir (Çabuk vd., 2017).

Oksijenatör sistemli karıştırıcı uygulaması ile metal işleme sıvılarının sürekli karıştırılması ve aynı zamanda oksijen sağlanması ile hazne üzerindeki talaş birikmesi önemli ölçüde azaltılır. Karıştırıcı ünitesi kullanımı ile bakteri miktarı kayda değer şekilde azalmaktadır (Puneeth ve Prasad, 2019).

\subsection{2. İzolasyon}

Çalışanları mekanik taşıma parçaları ve makine mahfazaları ile akışkanlardan uzak tutulması cilt ve solunum maruziyetini azaltabilir. Düşük verimli makineleri için basit sıçrama siperi yeterli olabilirken yüksek verimli makineler için genellikle tam mahfaza (havalandırmalı) gerekmektedir. Çalışanların izolasyon bölmeleri ve temiz oda hava duşları ile korunması tavsiye edilir (The National Institute for Occupational Safety and Health (NIOSH), 1998).

\subsubsection{Havalandırma}

Çalışanların işyerlerinde metal işleme sıvılarının aeorosellerine maruziyetini azaltmak için hava yoluyla gelen kirleticilerin birikmesi ve resirkülasyonu (dolaşımını) engelleyecek lokal (egzoz) havalandırma sistemi kurmak ilk başvurulan araçlardan biridir (Occupational Safety and Health Administration (OSHA), 1999). Ekipmanlarda akışkanlardan kaynaklanabilecek kirleticilerin kaynağında yakalanıp yok edilmesi içi kullanılan sis gidericilerin de bir çeşit lokal havalandırma sistemi olduğu söylenebilir.

Talaşlı şekillendirme işlemleri sonucu oluşan buğu, buhar, toz ve aerosollere maruziyeti azaltmada lokal havalandırma tek yöntem değildir. Sınırlı bir egzoz kaynağın dışında; genel veya seyreltici havalandırma sistemleri, belli bir alana göre belirlenen besleme ve egzoz havalandırması yoluyla kirletici konsantrasyonlarını kontrol etmeye dayanır (Occupational Safety and Health Administration (OSHA), 1999).

Seyreltici havalandırma sistemi lokal havalandırmadan gibi emisyonları kaynağında yakalayıp havayı temizlemek yerine kirleticilerin çalışma ortamı havasına yayılmasına müsaade eder ve sonrasında büyük miktarda havayı çalışma ortamına içine göndererek ortam havasındaki kirlilik konsantrasyonunu azaltarak havayı seyreltir. Genel anlamda, lokal havalandırmanın hava kirleticilerin kontrolünde ve çalışanların korunmasında seyreltici hava akımına göre daha etkili olduğu söylenebilir (Occupational Safety and Health Administration (OSHA), 1999). 


\subsection{4. İyi Çalışma Uygulamaları}

İş uygulamaları, mühendislik kontrollerinden farklı olarak işlerin yapılış şekillerini kapsar. OSHA'nın belirlemelerine göre iş uygulamaları maruziyeti azaltabilmektedir. Bazı temel ve kolay uygulanabilir iş uygulamaları:

(1) Doğru kişisel hijyen uygulamaları

(2) Koruyucu ve nemlendirici kremlerin kullanılması

(3) İyi bakım (temizlik dahil) uygulamaları

(4) Prosesin periyodik muayene ve bakımı ile ekipmanların kontrolü

(5) Uygun görev prosedürlerinin kullanımı

(6) Uygun prosedürlerin takip edilmesini teminen denetimin sağlanması (Occupational Safety and Health Administration (OSHA), 1999)

Metal işleme sıvıları ile çalışmalarda bu maddeler kapsamında değerlendirilebilecek aşağıdaki iyi işyeri uygulamalarını da hayata geçirmek mevcut teknik ve organizasyonel tedbirlerin etkinliğini arttıracaktır:

- Yeni bir emülsiyon hazırlamadan önce mutlaka sistem (tezgâh içi ve tezgâh tankı) temizliği ve dezenfeksiyonun yapılmalıdır. Bu kapsamda sadece mekanik temizlik değil ulaşılamayan ve ölü noktalardaki bakteri, mantar temizliği için de gerekli kimyasal işlem uygulanmalıdır. Emülsiyon olarak hazırlanan metal işleme sıvılarında genellikle $\% 95$ su, $\% 5$ metal işleme sıvısı yer alır ve suyun kalitesi büyük önem teşkil eder. Yumuşak su köpük sorununa, sert su ise emülsiyonun kesilmesine neden olabilmektedir. Eğer su uygun kalitede değilse su arıtma cihazlarının kullanılması veya uygun nitelikte hazır su alınması tavsiye edilmektedir. Üretimin durduğu zamanlarda her 48 saatte bir en az 1 saat metal işleme sıvisının sistemde sirkülasyonu sağlanmalıdır. Akışkan haznesinin en az her yılda bir boşaltılarak, sistemin ve kanalların düzgünce temizlenmesi akabinde tekrar doldurulması daha uzun ömürlü emülsiyona sahip olmak için gereklidir (3-S Mühendislik, 2011). Prosesin iki günden fazla süren durmalarında da emülsiyon mutlaka günlük olarak havalandırılmalıdır (Belgin Madeni Yağlar, 2019).

- Metal işleme sıvıları ile sürekli temas içerisinde olan çalışanların (operatörler, bakımcılar vb.) vardiya öncesi derinin maruz kalacak kısımlarını uygun bir krem (vazelin lonolin vb.) ile kremlemesi ve vardiya sonu yumuşak bir sabun vb. bir temizleyici ve bol su ile yıkayıp tekrar kremlemelidir. Bu bağlamda temizleyicilerin cildin koruyucu tabakasına zarar vermeyecek türde olmasına önem verilmesi gerekmektedir (Bruins ve Drager, 1975).

- Operatörün çalışma esnasında tezgâha çok yakın olmaması, ortamdaki havalandırma ekipmanlarının doğru çalışması ve soğutma sıvısına eklenen malzemelerin belli bir seviyede tutulmasına ilişkin hususların sürdürülebilirliği için kontrol mekanizması kurulmalıdır. Aksi takdirde bu hususlar operatörün metal işleme sıvısının buharını solukla içine çekmesine zemin hazırlar. Metal işleme sıvısının $\mathrm{pH}$ seviyesi düzenli aralıklar kontrol edilmelidir. $\mathrm{pH}$ seviyesinin 9,5'dan fazla olması durumunda sağlık riskinin artacağı dikkate alınmalıdır (Anaç \& Ay, 2004).

- Bor yağının su içinde karışması sırasında yağ damlacıklarının olabildiğince küçük olması karışımın kalitesini gösterir ve sıvının özelliğini uzun süre korumasına işarettir. Bunun için akışkan üreticileri tarafindan, karışımın içine sıvı sabun (arap sabunu vb.) ya da sabun yerini tutan kimyasallar eklenir. Bor yağı-su oranı, kullanma amaçlarına göre \%1 ile \%20 arasında değişir. Talaşlı imalat sırasında metal talaşları uzaklaştırılırken kendisine yapışan yağ damlacıklarını da beraberinde götürür. Emülsiyonun bileşenlerinden su, talaşlar üzerinden damlayarak soğutma sistemine geri dönmekte iken yağ talaşların üzerinde kalmaktadır. $\mathrm{Bu}$ nedenle emülsiyonda yağ azalması olmaktadır ve bu da sürekli kullanılan bor yağlarının zaman içerisinde özelliklerini yitirmesine yol açmaktadır. Bu sebeple emülsiyonun zaman zaman ölçülerek gerekli yağ ilâvelerinin yapılması faydalı olacaktır. Diğer sorun da su eksilmesidir. Özellikle sıcak ortamlarda yapılan çalı̧̧malarda; 1sı nedeniyle karışım içindeki suyun buharlaşıp azalması sorun oluşturmaktadır. Bu kez emülsiyonun soğutma özelliğinin azalmaması için yapılacak ölçümlerin neticesine göre karışıma gerektiği kadar su ilâvesi yapılmalıdır (Makine Eğitimi, 2020).

\subsubsection{Eğitim}

Metal işleme sıvıları ile çalışanlara gerek iş güvenliği uzmanı ve işyeri hekimleri tarafından verilecek temel iş sağlı̆̆ 1 ve güvenliği eğitimlerinde gerekse de bilgi sahibi ve deneyimli çalışanlarca verilecek uygulamalı işe başlama (oryantasyon) eğitimlerinde tehlikeli kimyasallara yönelik genel hatta klişe bilgilerden ziyade kullanılan akışkana özgü operasyonel bilgilerin verilmesi önem teşkil etmektedir. Özellikle işyeri hekimi tarafindan verilecek hijyen eğitiminin söz konusu akışkanlara ilişkin hijyen koşullarının önemini kavratacak ve çalışanların kişisel hijyen alışkanlıklarında davranış değişikliğine de yol açabilecek mahiyette olması ve çalışanların sağlık gözetimi hakkında bilgilendirilmeleri hususları dikkate alınmalıdır. 
Çalışanların İş Sağlığı ve Güvenliği Eğitimlerinin Usul ve Esasları Hakkında Yönetmelik'e göre verilmesi gereken tütün ürünlerinin zararları ve pasif etkileşim konusundaki eğitimde, metal işleme sıvılarının aerosollerinin solunum etkilerinin sigara dumanı ile ilişkisi de dikkate alınmalıdır.

\subsubsection{Kişisel Koruyucular}

Metal işleme sıvılarına maruz kalan çalışanlar için koruyucu ekipman, kullanıcıları kimyasallardan, delinmelerden, kesik ve sıyrıklardan korumalıdır. Çalışanlar, ciltlerini metal işleme sıvılarıyla temastan korumak için uygun eldivenler, kolluk, önlükler, pantolonlar ve başlıklar giymelidir. Saf kimyasallarla çalışırken kimyasal sıçramasına karşı koruyucu gözlük ve yüz siperleri gibi göz koruyucular giyilmelidir ve akışkanlarla göz temasını önlemek için diğer birçok işleme prosesi için yan siperleri olan güvenlik gözlükleri takılabilir ve cilt maruziyetine ilişkin koruyucu kremler / merhemler kullanılabilir (Occupational Safety and Health Administration (OSHA), 1999).

\section{Sonuc}

Metal işleme sıvılarına genel anlamda bir su ve yağ karşımı olarak bakılmadan tehlikeli kimyasalların yönetimi kapsamında işyerlerinde iş sağlığı ve güvenliği profesyonellerince daha fazla önem verilmesi gerektiği aşikârdır. Su-yağ karışımı dışında sıvı içerisindeki katkı malzemeleri ve yağ buharına maruziyetin sağlığa verdiği ciddi zararlar üretici ve tedarikçi bilgileri de elde edilerek iş sağlı̆̆ı ve güvenliği profesyonellerince detaylı bir şekilde sorgulanmalıdır. Akışkanla temas eden çalışanların eğitim ve bilgilendirilmelerinin doğru ş̧ekilde yapılabilmesinin birinci şartı kullanılan akışkanın zararlarının ve kontrol parametrelerinin iyi bilinmesidir.

Metal işleme sıvılarının iş sağlığı ve güvenliği yönünden önemli bir risk etmeni olduğu birçok ülke tarafından kabul edilmektedir. $\mathrm{Bu}$ sebeple söz konusu akışkanlara maruziyetin kontrolüne ilişkin yapılacak risk değerlendirmesinde kullanılmak üzere bahsi geçen tehlikeli kimyasallara ilişkin ulusal ve uluslararası düzenlemeler dikkate alınarak güncel verilerin toplanması önem teşkil etmektedir. Bu bağlamda tehlikeli kimyasalların yönetimine ilişkin düzenlemeler yanında güvenlik bilgi formları, mesleki maruziyet sınır değerleri ve iyi uygulama örnekleri yol gösterici nitelik taşımaktadır.

Ulusal mevzuatta metal işleme sıvıları için belirlenmiş bir maruziyet sınır değeri olmaması, güvenlik bilgi formlarında sunulan bilgilerin ticari sır kapsamında kısıtlanması, bu konuya yönelik çalışmaların sınırlı olması ve meslek hastalığı bağlamının kurulmasında yaşanan sistemsel sorunlar metal işleme sıvılarına gereken yaklaşımın gösterilmesine engel olabilmektedir. Ancak birçok ülkede söz konusu akışkanlar için yasal olarak belirlenen maruziyet sınır değerlerinin altında dahi hastalıkların gelişebildiği ve kompleks yapıları da dikkate alınarak maruziyetin olabildiğince aşağıya çekilmesinin en güvenli yaklaşım olacağı belirtilmektedir.

Metal işleme sıvıları ile çalışmalarda havalandırma, buhar (sis) toplayıcı vb. mühendislik kontrollerinin uygulanması ile ısınan akışkanın buharlarına maruziyetin önemli ölçüde azaltılacağının farkına varılmalıdır. CNC makinelerinde yaygın olarak kullanılan söz konusu akışkanlarda operasyonun kapalı alanda yapıldığı yanılgısı ile havalandırma ihtiyacı olmadığı ve ekipmandan doğrudan gözle görülür bir yayılım olmadığı düşünülmemeli işletmeler ve operatörler kendini güvende hissetme yanılgısına düşmemelidir.

Metal işleme sıvıların hazırlanması ve düzenli bakımının yapılması dahil kullanım süreçlerinin yakın takibi çalışanın maruziyetinin azaltılmasında önem teşkil etmektedir. Bu süreçlerin geleneksel yöntemler ve klişe bilgiler üzerinden ziyade sistematik ve operasyonel bilgiler ile yönetilmesi ilerde ortaya çıabilecek ciddi sağlık sorunlarının azaltılmasında önemli rol oynayacaktır. Bu kapsamda soğutma sıvısının kontrolünün düzenli olarak yapılması, konsantrasyon, $\mathrm{pH}$, yabancı yağ, pas, iletkenlik, bakteri ve mantar miktarları vb. kontrolleri yapacak kişilerin belirlenmesi ile mevcut havalandırma ve yağ sistemin filtrelerinin düzenli temizlik ve değişimleri önem teşkil etmektedir.

Metal işleme sıvısının seçiminde teknik ihtiyaçların yanı sıra işyeri hekimi ve iş güvenliği uzmanının önerilerine de başvurularak çalışan sağlığına ilişkin zararlar da dikkate alınmalıdır. İşyeri hekimince söz konusu akışkanlarla çalışan operatörler için cilt ile temasta alerjiye yatkınlık hususu da dikkate alınarak tıbbi yakın takibin yapılması tavsiye edilmektedir.

Metal işleme sıvılarının karmaşık kimyasal yapıları, kullanılan katkı maddelerinin fazlalığı, bunların üreticiler tarafından sıklıkla değiştirilebildiği ve kullanıldığı işlem ve çalışma ortamına göre farklı maruziyetlerin otaya çıkabileceği hususları yapılacak risk değerlendirmelerinde özenle üzerinde durulması gereken hususlardır. 


\section{Kaynaklar}

Akkurt, M. (2004), Talaş Kaldırma ve Takım Tezgahları, Birsen Yayınevi.

Air Quality Engineering, https://www.air-quality-eng.com/products/mistbuster-500/. (Erişim tarihi: 27 Nisan 2020).

Anaç, N., Ay, İ. (2004), Soğutma Sıvılarının İnsan Sağlığına Etkileri, Metalmakina, 149.

Belgin Madeni Yağlar. (2019), Su İle Karışan Metal İşleme Sıvıları Kullanım Bilgileri, https://www.tezmaksan.com.tr/su-ile-karisan-metal-isleme-sivilari-kullanim-bilgileri.pdf. (Erişim tarihi:25 Nisan 2020).

Bruins, D. H., Drager, H. J. (1975), Talaşlı Metal İşlemede Takımlar ve Takım Tezgahları.

Burton, N. C. (2008), Preventing Health Hazards from Metal Working Fluids, NIOSH Science Blog.

Canadian Centre for Occupational Health and Safety, OSH Answers Fact Sheets, https://www.ccohs.ca/oshanswers/chemicals/metalworking_fluids.html. (Erişim tarihi:25 Nisan 2020).

Canter, N. (2019), Metalworking fluids:The quest for bioresistance, Tribology and Lubrication Technology, $75(3)$.

Çabuk, H., Akkuş, G., Soyusinmez, T. (2017), Soğutma Sıvısı Bulutunun Vakumlu Santrifüj Yöntemi İle Geri Kazanımı ve Temiz Hava Elde Edilmesi, Mühendis Ve Makina, 58(684).

Çalışma ve Sosyal Güvenlik Bakanlığı. (2013), Kimyasal Maddelerle Çalışmalarda Sağlık Ve Güvenlik Önlemleri Hakkında Yönetmelik.

Çevre ve Şehircilik Bakanlığı. (2012), Metal Sektörü Rehber Dokümanı.

Demir, H. (2009), Talaşlı Üretimde Kullanilan Kesme Sıvılarından İstenen Özellikler, Uluslararası İleri Teknolojiler Sempozyumu (IATS’09), Karabük.

Erel, F., Coşkunses, F. I. (2012), Metal İşleme Akışkanları Kullanımında İş Sağlığı ve Güvenliği, İş Sağlığı ve Güvenliği Araştırma ve Geliştirme Enstitüsü, Ankara.

Frank, R., Revonna M. (2011), Physical Hazard Control", Government Institutes, U.S.A.

Gorny , R., Szponar, B. (2004), Metalworking fluid bioaerosols at selected workplaces in a steelworks, American Journal of Industrial Medicine(46), 400-403.

Gündoğdu, H. (2006), Kesme Sıvılı Ve Kuru Talaşlı İşlemenin İş Parçası ve Kesici Takım Üzerindeki Etkileri, Yüksek Lisans Tezi, Yıldız Teknik Üniversitesi, Fen Bilimleri Enstitüsü.

Health and Safety Executive(HSE). (2007), RR577-The causative factors of dermatitis among workers exposed to metalworking fluids.

https://www.makinaegitimi.com/sogutma-sivilari-nelerdir-sogutma-sivilari-hakkinda-bilgi/. (Erişim tarihi: 27 Nisan 2020).

İş Sağlığı ve Güvenliği Genel Müdürlüğü. (2013), Çalışma Yaşamında Sağlık Gözetimi Rehberi, Türkiye'de İşyerlerinde İş Sağlığı ve Güvenliği Koşullarının İyileştirilmesi Projesi (İSGİP).

Kavuncu, İ. (1975), Metal İşlemede Kesme Yağları. Tmmob Makine Mühendisleri Odası, Ankara.

Kuram, E. (2009), Bitkisel Esaslı Kesme Sıvılarının Delmedeki Performansının Araştırılması, Yüksek Lisans Tezi, GYTE-Mühendislik ve Fen Bilimleri Enstitüsü, İstanbul. 
Lubriserv Metalworking Fluids and Equipment, https://www.lubriserv.com/machine-and-coolant-cleaningservice/. (Erişim tarihi: 25 Nisan 2020).

Master Chemical Corporation (Master Fluid Solutions). (2005), Characteristics of Metalworking Fluids - Foam, Teknik Bülten.

Nune, M. M., Chaganti, P. K. (2019), Development, characterization, and evaluation of novel eco-friendly. Measurement(137), 401-416.

Occupational Safety and Health Administration (OSHA). (1999), Metalworking Fluids: Safety and Health Best Practices Manual.

Osama, M., \& Singh, A. (2017), Recent developments and performance review of metal working fluids, Tribology International(114), 389-401.

Petroyağ ve Kimyasalları San. ve Tic. A.Ş., Metal Working Fluids.

Puneeth, H., \& Prasad, M. (2019), Biological factors influencing the degradation of water-soluble metal working fluids. Sustainable Water Resources Management(5), 1357-1367.

Schinkel , L., \& Lehner, S. (2018), Transformation of chlorinated paraffins to olefins during metal work and thermal exposure, Chemosphere (194), 803-811.

Şahin, Y. (2001), Talaş Kaldırma Prensipleri 2. Nobel Yayın, Ankara.

The National Institute for Occupational Safety and Health (NIOSH). (1998), Criteria for a Recommended Standard Occupational Exposure to Metalworking Fluids.

United Kingdom Lubricants Association (UKLA). (2018), Good Practice Guide for Safe Handling and Disposal of Metalworking Fluids.

Washington State Department of Labor and Industries. (2001), Prevention of Skin problems When Working with Metal Working Fluids Techincal Report.

Wisley, S. F., Anselmo, E. D., Alisson, M. (2001), Application of cutting fluids in machining processes, Journal of the Brazilian Society of Mechanical Sciences, 23(2).

Yücel, E., Günay, M., Ayyıldız, M. (2011). Talaşlı İmalatta Kullanılan Kesme Stvılarının İnsan Sağlığına Etkileri Ve Sürdürülebilir Kullanımı. 6th International Advanced Technologies Symposium (Iats'11), Elazığ.

3-S Mühendislik. (2011). Soğutma Slvlsı/Metal İşleme Slvlsı Bakımı. Redüktör Dergisi, 2011(1).

\section{Conflict of Interest / Çıkar Çatışması}

Yazarlar tarafından herhangi bir çıkar çatışması beyan edilmemiştir. (No conflict of interest was declared by the authors.) 